\title{
Entrevista de Pierre Bourdieu com Yvette Delsaut Sobre o espírito da pesquisa
}

Tradução de Paulo Neves

Eu quis que tivéssemos esta conversa porque não queria deixar essa bibliografia sem seu contexto. Pareceu-me que muitos não-ditos ficavam ocultos entre as linhas, que faltavam explicações, ao mesmo tempo, sobre as razões que a fizeram nascer, a evolução que ela conheceu, as implicações que sabemos, o senhor e eu.

Isso me dá a ocasião de dizer o profundo reconhecimento que sinto por esse trabalho. Eu disse com freqüência que a pesquisa francesa e mesmo toda a nossa tradição intelectual nacional sofriam muito com o fato de que al gumas atividades, indispensáveis mas tradicionalmente tidas como inferiores (em Les $\mathrm{H}$ éritiers [O s herdeiros] ${ }^{1}$ citava-se Péguy catalogando $M$ auss como "cesto de fichas"!), não eram nem bastante desenvolvidas nem bastante reconhecidas e recompensadas. Estou consciente, portanto, de ter muita sorte de que um tal instrumento de trabalho tenha sido produzido, e desejo que o considerem uma obra integral, como elemento de uma tecnologia social específica.

Lembro, primeiro, que essa bibliografia já foi publicada duas vezes antes da presente edição, uma primeira vez em 1984 e uma segunda em 1990. As condi ções de publicação dessas duas edi ções anteriores eram completamente arte sanais, tratava-se, na prática, de auto-edições². A seguir abandonei essa atualização bibliográfica, que depois de mim foi assegurada por $\mathrm{M}$ arieC $\mathrm{Christine}$

1. Les H éritiers, lesétudiantset la culture, com J. C. Passeron [1964].

2. Bibliographie des travaux dePierreBourdieu, estabelecida por Y. D elsaut, Paris, Centre de SociologieEuropéenne, 1984; publicadaem edição alemã em P. Bourdieu, Sozialer 'Raum un Klassen', Leçon sur la leçon [1985]. Atualizada em Bibliographiedestravaux dePierreBourdieu, 19581988, mesmas referências, 1990; publicadaem edição inglesa em P. Bourdieu, In other words. Essays toward a reflexive sociology [1990]. 
Rivière. Essa passagem se fez sem palavras, porque eu havia abandonado 0 trabal ho com o senhor; ou seja, entre mi m e ela nunca houve um acerto explícito a propósito desse trabalho no qual me vi novamente envolvida, após mais de dez anos de distância. Digo isso porque acho quase milagroso que se tenha podi do fundir as duas partes em uma, sem outros problemas a não ser técnicos (porque meus procedimentos de registro, mesmo por computador, eram realmente uma bricolagem comparados ao refinamento de hoje). Sempre é citado Proust, que achava que havia romantismo na simples consulta a um guia ferroviário, como se fosse um paradoxo brincalhão. No mesmo gênero, créo que $M$ arie-Christine Rivière e eu temos em comum o fato de sentir uma satis fação íntima ao ver uma enumeração de títulos encaixarem-se racionalmente. Porque a busca da precisão das referências, que se verificam e tornam a ser verificadas, é um antídoto contra a inquietude de si, no universo muito gerador de ansi edade da produção intelectual, sobretudo quando há sempre muitas subversões, como acontece com o senhor.

Nem sempre the facilitei as coisas, porque nem sempre compreendia suas resoluções ou só as compreendia muito tarde.

Sim, e ao mesmo tempo não há como não se envolver nesse trabalho, certamente mais do que seria preciso... A contece mesmo de sentirmos uma verdade ra emoção estética: lembro-me do fascínio que senti quando vi chegar a tradução italiana L'opinione pubblica non esiste, que me parecia muito mais formi-

3. “' $\mathrm{L} O$ pinion publique n'existe pas" [1971]. dável que L'O pinion publique n'existe pas [A opinião pública não existe] ${ }^{3}$, eu gostava de repetir o título italiano em voz alta. Há talvez uma doce maluquice em sentir-se bem na gestão minuciosa de uma bibliografia, mas não é porque se trabalha com "fichas" (embora elas não sejam mais materializadas, o sistema permanece o mesmo) que não se teria o direito ao respeito concedido a todos os apai xonados por alguma coisa. Estou convencida, em todo caso, que foi graças a uma relação de semelhança entre as duas autoras que a bibliografia encontrou sua unidade. Restam diferenças infinitesimais entre as duas partes, porque a passagem desse encargo coincidiu com sua passagem de uma editora a outra, da M inuit à Seuil, cada editora tendo suas próprias convenções ti pográficas que nós duas segui mos separadamente. N ão se jul gou útil ir até os menores detal hes na harmonização do trabalho de conjunto.

0 que pode afigurar-se como um simples registro positivista (é assim que o tratam, em realidade, os que dele se utilizam sem citar as fontes, ou 
que reproduzem trechos inteiros, inclusive os erros, para produzir "bibliografias parciais" consagradas a um tema particular) é uma verdadeira criação intelectual, que envolve uma quantidade de escolha que deve ter alguns de seus princípios explicitados, acredito, para que vocês não sejam mal compreendidas.

Sim, certamente, e pelo senhor em primeiro lugar... Porque sempre que uma regra era estabelecida, o senhor reintroduzia os problemas que essa regra havia permitido resolver.

Vocês foram obrigadas a fazer escolhas, seja sozinhas, seja em concordância comigo...

Q uando comecei a me ocupar com essa bibliografia, não percebi de imediato que fazia escolhas. Passei a fazêla para pôr ordem, simplesmente: quando os textos chegavam, eu os registrava. $\mathrm{Na}$ época, era algo completamente manual, não se podia fazer malabarismo com as referências, elas se acrescentavam umas às outras, por isso as escol has, como o senhor disse, eram limitadas. D e minha parte, eu fazia tudo cronologicamente. Se havia ainda assim uma regra imperativa, era que os textos, para serem registrados, deviam estar publicados, isto é, conter referências bibliográficas. Q uanto ao estrangeiro, as informações me chegavam geralmente por intermédio dos tradutores que trabalhavam com seus textos. É preciso falar desses tradutores, porque, no começo, houve toda uma pequena confraria: atraídos talvez por esse tipo de sociologia, eu achava que todos se assemelhavam um pouco - cada um com suas características nacionais, seu sotaque particular. Penso em Richard Teese, por exemplo, um pioneiro que produziu Bourdieu na Austrália com os primeríssimos textos sobre a educação. Penso em Richard Nice, Bernd Schwibs, eles traduziram La Distinction ${ }^{4}$ praticamente ao mesmo tempo, um em alemão, 0 outro em inglês, ajudando-se mutuamente, sem que o soubessem, por meu intermédio; e também em Sergio M iceli e M ihai G heorghiu. G heorghiu publicou na Romênia, no tempo de Ceaucescu, traduções que só foram publicadas em inglês, pela Polity Press, bem mais tarde. Q uando registrava todos esses trabalhos, muita atenta em fazer respeitar a cronologia, eu achava que estava sendo justa, que punha na frente os mais meritórios e no fim da fila osúltimosa chegar, pondoos em seu devido lugar, sobretudo se eram grandes casas editoriais que haviam tido tempo para calcular os riscos. $\mathrm{Na}$ verdade tomei consciência disso muito recentemente, quando vi o trabalho de $\mathrm{M}$ arie-Christine Rivière: ela havia
4. La Distinction. Critiquesocialedu jugement [1979]. 
tomado um partido inverso, repertoriando primei ro as traduções mais comple tas, e geralmente as mais tardias, para indicar a seguir a longa série de traduções parciais espalhadas um pouco em toda parte, numa ordem decrescente de importância, em função de sua facilidade de acesso, numa preocupação de eficácia documental. Finalmente decidiu-se unificar as coisas, adotando a ordem cronológica em tudo, de modo que as publicações pioneiras continuam citadas em primeiro lugar.

É verdade que, no começo, os primeiros lançamentos no estrangeiro ocorreram de forma surpreendente, como nos M elbourneWorking Papers, ou em obscuras publicações marxistas. M as, como o critério consistia em tomar apenas os textos publicados, isso excluía muitas coisas. 0 perigo está também em osleitores não compreenderem o quefoi investido nesse trabaIho, sobretudo no começo. A bibliografia foi feita, de início, dentro do movimento da pesquisa, por alguém que, participando da pesquisa, nela investia uma visão da pesquisa que me parece justa, mas que temo não seja aquela que a maioria dos leitores adotará em sua leitura.

Sim, éverdade, eu aderia totalmente ao movimento, estava realmente dentro dos textos, e, se catalogava duas vezes o mesmo texto, sob o mesmo título, eu sabia exatamente o que se havia passado entre os dois momentos. Estava contente de fazer isso, como se eu vigiasse a eclosão de alguma coisa, como se fizesse meu trabal ho de membro da equipe. No começo, em todo caso, era como uma contribuição a um trabal ho coletivo. Eu aderia a tudo aquilo, que parecia não se mexer e se mexia o tempo todo; era preciso fixar as coisas mas como algo provisório, que tornaria a mudar e seria preciso fixar de novo, era realmente assim.

Você me disse um dia, e isso me causou um choque, que eu trabalhava ao acaso, sem direção... D e fato, havia uma grande parte de improvisação, e 0 acaso desempenhava um papel muito importante em minhas escolhas (de objeto, de método, de colaboradores etc.), mas ao mesmo tempo era algo muito "refletido", muito pensado. Poder-se-ia falar de estratégia, no sentido como a entendo, isto é, de condutas que, por terem nascido de um mesmo princípio, podem dar a impressão de serem o produto do cálculo sem que tenham sido de modo al gum calculadas, e de terem algo de sistemático sem que decorram de uma intenção de sistematicidade. Acho que eu poderia traçar para mim duas biografias intelectuais completamente diferentes, uma que faria ver todas as minhas escolhas sucessivas como 0 
resultado de um projeto metodicamente orientado, desde a origem, e outra, igualmente verdadeira, que descreveria um encadeamento de acasos, de encontros mais ou menos fortuitos, felizes ou infelizes... Estou certo, em todo caso, que há constâncias, as de um habitus, marcadas sobretudo em recusas, eque a bibliografia registra sob a forma de locais de publicação (quese deveria sempre poder re-situar em relação aos possíveis outros afastados, por exemplo a M inuit em relação à Gallimard), títulos de revistas, nomes de entrevistadores ou de tradutores.

0 fato de eu ter estado envolvida é importante para compreender o que aconteceu com essa bibliografia. Eu realmente nunca me coloquei a questão de sua difusão, por exemplo; esse documento permaneceu até hoje no estado de fascículo modesto, sem que jamais se tenha decidido se ele deveria ser considerado uma publicação (etratado como tal) ou um documento interno. H á uma espécie de anonimato voluntário na realização desse tipo de trabalho, o que não quer dizer que ele seja neutro. É o caso do "historiador original", que está na história mesma que ele conta e que pode, por essa razão, embora sendo muito verídico, omitir o essencial, isto é, que ele faz parte da história. Fui obrigada a refletir sobre isso ao descobrir, em trabalhos a seu respeito, bibliografias parciais cuja realização os autores implicitamente se atribuíam, talvez com toda a ingenuidade (o que mostra bem o desprezo que cerca esse tipo de trabalho de recensão metódica: esquece-se mesmo que há um autor), ou bibliografias tentaculares na Internet, com nomes importunos e pós-modernos, como $\mathrm{H}$ yperBourdieu, e construídas segundo uma filosofia que nada tem a ver com a maneira como resolvi fazer a minha. 0 exemplo de $\mathrm{H}$ yperBourdieu (que tomo porque o nome éfácil de reter - tanto pior para eles, não deviam ter-se batizado assim, aliás foi fei to para que o retivessem, um nome de marketing, como hipertexto, hiperlink) mefez refletir muito. É um site austríaco, feito por universitários de Linz, sobre seus trabalhos.

Sim, andei vendo. Vi que tinham inclusive um copyright para a bibliografia que fizeram, custei a compreender isso; o que é esse direito de propriedade autoproclamado sobre dados que vêm necessariamente de outras fontes (aliás declaradas, num outro estágio do trabalho deles 5 )?

Será que eles querem proteger seus direitos sobre o trabalho de montagem do site? $\mathrm{N}$ ão sei como funciona juridicamente, mas ainda assim é um pouco arrogante, ainda mais por eles parecerem pretender uma exclusividade ("We now
5. I. M örth eG . Fröhlich, D as symbolische Kapital der Lebensstile. Zur Kultursoziologieder M oderne nach Pierre Bourdieu, Frankfurt/N ova York, Campus Verlag, 1994, pp. 271-311. 
6. Trata-se aqui do Centro de Sociologia Européia(CSE), fundado por R. Aronem 1959, do qual P. Bourdieu era o secre tário geral desde1962. A partir de 1970, cindiuseem doiscentrosdepes quisadistintos; um deles, desdeentão, passou aser dirigido pelo próprio P. Bourdieu, conservando 0 nome de origem acres centado de umadesigna ção autônoma, Centro de Sociologia da Educação e da Cultura (CSEC). claim completeness for all works and public statements, which have been published or broadcasted in French, English or German"), deve ser o equivalente de "direi tos reservados para todos os países". Além disso, acho esse desdobramento asfixiante quando o percorremos, porque tudo está no mesmo plano, é mais uma barreira do que um auxílio ao conhecimento de sua bibliografia, imagina-se que jamais se consegui rá abarcar tudo. $M$ as, na segurança que eles demonstram, sinto também - e é mais grave por ser uma doutrina tenaz toda uma ideologia da distância. Eles são totalmente exteriores ao seu universo, o conhecimento que têm da língua francesa é muito rudimentar (dão algumas amostras ridículas desse francês), isto é, o conhecimento que eles têm do senhor é mediatizado pelas traduções, alemãs e inglesas essencialmente. (E sse aspecto "línguas europé as dominantes" é um pouco desagradável em seu princípio, e também quando penso nas traduções italianas, portuguesas, espanholasque existem há tanto tempo... ) C om isso, portanto, o quepoderia caracterizálo como estando situado num campo acadêmi co naci onal desaparecetotalmente. O senhor se torna uma abstração, um espírito. E eles não apenas não parecem colocar-se a questão da própria competência como também, num anexo crítico, condenam em termos muito duros as pessoas que lhe são próximas, que puderam escrever a seu respei to e que são desqualificadas pelo simples fato de serem próximas. M as será que a completa exterioridade é realmente uma garantia? Será que se deve pensar obrigatoriamente a proxi midade em termos de alienação, de dominação, de dependência, de obsequiosidade? É verdade que existe algo de particular na posição de um próximo, mas que me parece ser mais da ordem da tranfferência. Poder-seia falar de uma sensibilidade mútua às particularidades do outro, porque o senhor também é tocado por essa proximidade, não é um processo em sentido único.

Isso é evidente e tenho consciência de ter sido extraordinariamente sustentado, carregado mesmo, especialmente no período de acumulação primitiva do capital, pela espécie de "fusão" ao mesmo tempo intelectual e afetiva que unia todos os membros do grupo ${ }^{6}$.

Q uando eu trabalhava com o senhor, havia verdadei ros laços de proj eção entre as pessoas. Lembro uma época, no Centro, éramos todos jovens (o senhor mesmo não tinha muito mais idade que nós, era apenas nosso irmão mais velho), os rapazes tinham todos mais ou menos um pouco do sotaque do sudoeste, como o seu, quando falavam a palavra sociologia; era divertido. Falava-se uma gíria de normalista que vinha diretamente também de sua boca, 
não se falava de "porcentagem de fracassos nos exames", mas dos que "rodaram" ( bités) nos exames... Fi cávamos contentes de saber introduzir num texto expressões suas, "elou", ou então mutatis mutandis, "tratando-se de", e também "inseparavelmente", eu poderia dizer muitas outras, "romper com", "no princípio de"...

Sim, havia também, nos textos, uma forma característica de introdução, que fazia desfilar sempre os erros anteriores etc. Brincávamos com isso, entre nós... Sim, de fato, era isso mesmo, um coletivo...

$N$ ão é suficiente dizer que é um coletivo: um coletivo, certamente, mas com um ponto de atração muito visivelmente instituído. A reciprocidade entre 0 senhor e nós se dava num outro registro: formávamos um círculo a seu redor, ao mesmo tempo respeitoso e sem cerimônia, que por certo Ihe era reconfortante, e o senhor nos propunha um modelo intelectual, encarnado em sua pessoa, e que era igualmente respeitável e sem cerimônia. N ão gostávamos que falassem mal do senhor, assim como o senhor não tolerava que criticassem os membros do seu grupo, pode-se dizer que havia realmente uma espécie de solidarie dade orgânica. Tinha-se 0 sentimento de que as iniciativas individuais 0 comprometiam e comprometiam o grupo, e que era preciso pensar nelas antes de agir. E nos sentíamos mais ou menos feridos se um de nós agisse no mundo profissional exterior sem falar disso antes. M as não setratava de um falanstério igualitário. 0 senhor era muito íntimo conosco, tinha uma maneira particular de brincar verbalmente com as pessoas, mas sempre achei que isso era um modo de tratamento familiar sem nos dizer "tu", o que não é de modo algum a mesma coisa. Aliás, é revelador que o espírito de maio de 1968 não tenha estritamente alterado nada disso: o "tu" não se introduziu entre o senhor e nós, enquanto florescia em toda parte, e não passamos a citar nomeadamente, um por um, a totalidade do pessoal do centro de pesquisa nos cabeçal hos das publicações, tal como se instituiu por algum tempo no mundo intelectual.

É verdade, continuava havendo uma certa distância numa familiaridade muito grande.

$M$ as essa estrutura, que combinava hierarquia e proximidade, tinha um efeito de estimulação intelectual, tinha-se a impressão de que o inacessível estava a nosso alcance, mesmo se faltavam títulos justificativos. Q uanto a mim, em todo caso, foi essa estrutura, essa ilusão mágica que me permitiu ter um ponto 
de referência a partir do qual eu mesma me estruturei, intelectualmente, entenda-se; até então, eu não tinha nada que me ajudasse s mplesmente a enunciar algo de construído, a sustentar um ponto de vista; não que eu tivesse medo de falar: équetudo permanecia mal formulado, mesmo para mim, as queixas como as sati ffações, eu diria que não sabia pensá-las distintamente. Foi realmente $0 \mathrm{C}$ entro que me ti rou desse pequeno pântano intelectual.

Estou impressionado que você diga coisas assim...

Falávamos há pouco da legitimidade que parece naturalmente associar-se à exterioridade do ponto de vista: mas aqueles de seus amigos que publicaram análises sobre seus trabalhos são eles próprios muitas vezes contaminados por esse eterétíipo. Como se explica que escrevam sempre de forma tão categórica, como sefalassem do exterior, sem tirar argumento da proximidade com o senhor?

Eles fazem como se escrevessem um livro sobre um filósofo clássico; não por desonestidade, mas por um viés profissional. H á também uma recusa da complacência psicológica em falar de si, que é uma tradição interna de nosso grupo: não se derramar. 0 que é um modo de respeitarse e de respeitar.

I sso émais particularmente um modelo seu. E assim eles ficam numa situação complicada: ou conformam-se à imagem que o senhor tem da atividade intelectual (não se derramar etc.) e não tiram nenhuma vantagem da situação, ao mesmo tempo que se expõem à crítica, ou então infringem princípios que são seus, do senhor que etá no núcleo do trabalho deles. É uma posição difícil de sustentar.

$\mathrm{N}$ ão há motivo para aprovar ou para desaprovar. Em realidade, trata-se de um estilo, de uma maneira de ser, de comportar-se, que é sem dúvida a minha, mas que nunca precisei impor porque ela nos era mais ou menos comum, e é certamente o que nos havia aproximado (penso nas afinidades de habitus).

Volto outra vez ao caso dos austríacos do H yperBourdieu: o que também me impression ou no trabalho deles é que façam sistematicamente a caça aos inéditos. Parece-me que há uma contradição entre 0 fato de ocupar uma posição exterior, e dela se prevalecer, e ao mesmo tempo buscar o inédito para aproxi- 
mar-se do senhor como que por trás, para surpreendêlo num exercício não controlado. Eles fazem chamadas para recuperar, por exemplo, um velho texto que o senhor teria escrito sobre o Tour de France [torné o ciclístico anual] nos anos de $1960 \ldots$

D e fato, escrevi um texto sobre o Tour, uma pequena peça literária sem pretensões sociológicas, eu não era nem um pouco sociólogo naquela época...

M elhor ainda, do Bourdieu antes de tornar-se sociólogo!

Foi a pedido do meu amigo Michel Benamou'7, que preparava um manual de francês para estudantes americanos. Eis aí uma tarefa para nossos amigos do hipertexto!

M as eles já sabem, têm a referência, apenas pedem que se confirme ou não, 0 que significa que tiveram a referência de ouvir dizer, não sei como. M as eles remontam ainda mais em seu itinerário intelectual, citam um certo "projeto de tese" (de 1956), como se fosse uma obra de sua primeira juventude, o primeiro texto do jovem Bourdieu; ao situá-lo no Liceu de M oulins, não se compreende o que esse documento universitário estaria fazendo lá, a menos que 0 senhor o tenha esquecido quando deu aulas de filosofia nesse liceu; eles acres centam que é um manuscrito...

M as isso não tem interesse, não vejo de onde eles podem ter obtido essa informação ${ }^{8}$.

Eles citam também, remontando ainda mais acima, sua tese [DES, Diploma de Estudos Superiores] sobre as Animadversiones...

M as ela não está disponível em parte al guma, existe somente um exemplar e está em minha casa. É uma tradução prefaciada, anotada e comentada das Animadversiones de Leibniz; fiz com Gouhier, que me disse para publicá-la, mas hesitei e acabou não saindo9 .

0 mito do inédito repousa na idéa de que no mais íntimo do autor há um núcleo, sobre o qual vêm se sobrepor estratos sociais, dispositivos para enganar os outros, para instalar sua pessoa, e de que no menos controlado estaria o mais autêntico.
7. M . Benamou, LeM oulin à paroles méthode avancéedeconversation et de composition, $\mathrm{N}$ ova York, Blaisdell, 1963.

8. Esseprojeto detese, sobre "Les structures temporelles de la vie affective" (inscrita sob a direção de G. Ganguilem), não teve continuidade.

9. As Animadversiones foram traduzidas e publicadasnovamentepela Vrin, em 1982 (cf. G. W. Leibniz, Animadversionesin partem generalem Principiorum cartesianorum): seriainteres sante comparar as duas traduções. 
Sim, haveria o realmente verdadeiro, o puro, e por cima disso todo um trabalho de vestimenta social, de retórica...

D e defesa contra os adversários..

Q ueesconderia a pureza da mensagem original, que seespera redescobrir. $N$ ão é uma idéia completamente fal sa, porque é verdade que as censuras... Por exemplo, pode suceder-me de dizer com clareza, oralmente, coisas que o trabalho da escrita irá confundir, mascarar.

0 senhor parece pensar que o "espontâneo" seria mais franco do que o "trabaIhado": geralmente ele é mais simplista. Acontece mesmo de 0 oral simular 0 espontâneo para permitir-se uma fórmula-choque que de outro modo não pas saria porque seria uma abreviação muito sumária.

Sim, étodo o problema da passagem difícil da transcrição do oral para o escrito. Em realidade, o que receio sobretudo é que as pessoas que vierem a se interessar por essa bibliografia a vejam por meio de uma idéia preconcebida einconsciente da pesquisa. A lógica arrevesada - não há outra palavrada pesquisa, tal como a concebo, éfeita de uma longa série de retomadas...

10. La Reproduction, Élémentspour unethérie du système d'enseignement, com J. C. Passe ron [1970].

11. Esquissed'unethéorie dela pratique, précédéde trois études d'éthnologie kabyle [1972].

12. L'Amour del'art, les musées d'art et leur public, com A. D arbel eD. Schnapper [1966]. A segunda edição, aumentada, apareceu três anos após a primeira e intitulou-seL'Amour de l'art, les musées d'art européens et leur public [1969].
Essa palavra me ocorre porque acabo de ler um romance de Robbe-G rillet com esse título [Reprise]... Para mim, "retomada" não é algo que faz pensar em Kierkegaard, mas num trabal ho de costureira. M eu trabalho éuma eterna retomada, uma retomada sem fim. $\mathrm{H}$ á al go deenganador nos textosacabados, definitivos, ou mesmo "hiperacabados", se posso dizer, como La Reproduction (falo da primeira parte) ${ }^{10}$, em que tudo é feito para que desapareçam todos os vestígios da hesitação, do arrependimento, da rasura, em suma, do rascunho. $\mathrm{N}$ a verdade, até os anos de 1980 considerei a maior parte de minhas publicações - os artigos, é claro, mas também os livros rascunhos, um pouco como as mimeografias que circulavam no Centro (penso na que fiz com "O sentimento da honra na sociedade cabila" e "A casa cabila ou o mundo invertido", que circulou por muito tempo antes de tornar-se a primeira parte do Esqui sse [E sboço de uma teoria da prática] ${ }^{11}$ ). Aquilo me dava uma grande liberdade. Eu sabia que recomeçaria, de maneira melhor, mais definitiva, em outro artigo ou em outro livro. (Portanto, eu hesitava menos em publicar sem esperar.) Várias vezes exigi dos editores que prometessem deixar-me corrigir meu livro por ocasião da segunda edição. É o caso de L'Amour de l'art [0 amor pela arte] ${ }^{12}$, que praticamente 
reescrevi na segunda edição, ou de L'Esquisse d'une théorie de la pratique que, como diz o título, era apenas um esboço, que devia ser retirado devenda - estava previsto no contrato com a D roz - quando aparecesse o livro "definitivo", Le Sens pratique [0 sentido prático] ${ }^{13}$. D urante muito tempo me indispus com Jérôme Lindon por não ter concordado em publicar em francês a edição corrigida e aumentada de U n art moyen [U ma arte média], quenão obstante preparei para a tradução inglesa ou ital iana e que passou a fazer parte de meus documentos ${ }^{14}$.

É comprensível que um editor possa ter um ponto de vista diferente...

Sim, mas para mim é capital. Estou sempre voltando aos textos, tudo é revisto, linha a linha, mudo uma palavra aqui, uma palavra ali... Por exemplo, alguém observou que, num certo momento, ondeeu dizia "sistema", passei a dizer "campo" por ocasião de uma reedição ou de uma republicação...

Foi certamente um de seus tradutores, eu reconheço o reflexo!

Sim, mas é interessante. Eu não estava disposto a fazer uma grande exibição autocrítica, não é do meu feitio, tenho horror do grande estilo marxista-normalista: besteiras enormes são ditas e tira-se proveito delas, depois recolhem-se os lucros que há em corrigi-las numa tonitruante autocrítica. Eu sempre disse que não queria fazer isso. $\mathrm{M}$ as, por outro lado, não quero deixar circular um texto que sei imperfeito, nesse ou naquele ponto. Corrijo sem dizer nada. M as, em realidade, substituir "sistema" por "campo" é uma mudança de teoria. Só que essas mudanças se fazem aos poucos, passo a passo, por correções sucessivas que são, na verdade, rupturas.

Sè o que lhe colocou um problema na constituição dessa bibliografia, é o fato de se ter catalogado cuidadosamente todas as republicações.

Sim, por que conservar a primeira publicação?

M as há um interesse em mostrar as condições nas quais um texto nasceu, em que momento de seu itinerário...

Sim, talvez. M as por que os textos são catalogados em seu primeiro lançamento, quando eles foram republicados de uma forma mais acabada,
13. Le Sens pratique [1980].

14. Un artmoyen, essai sur les usages sociaux de la photographie, com L. Boltanski, R. C astel, J.-C. Chamboredon [1965]. U masegunda edição, re vista, foi no entanto publicada pela M inuit em 1970, sem as modifica çõesintroduzidasulteriormente. A edição italiana apareceu em 1972, a inglesa em 1990. 
portanto mais ou menos profundamente transformada? Q ual o interesse?

Q uando uma intervenção oral é publicada mais tarde, com a origem do texto são dadas informações sobre o lugar, as circunstâncias...

Certamente você tem razão, quando se age de boa-fé. M as pode-se também fazer uso disso para dizer: sim, ele repete sempre a mesma coisa... Esse é o problema-chave, para mim pelo menos, dessa bibliografia: se for vista por gente de boa-fé, que sabe o que é a pesquisa, tudo bem.

Creio queé exatamente por razões dessa ordem, uma atenção um pouco inquieta ao que vão dizer no momento da recepção (será que isso não étambém uma confi ssão de fraqueza?), que no começo desse trabal ho eu não assinalava as re publicações Aliás éo queeu digo com todas as letrasna advertência preliminar da primeiríssima edição, eque foi reproduzido a seguir tal equal, inclusive na presente edi ção: di go que as republicações intenci onais não estão regi stradas, "mesmo quando foram a ocasião de modificações, às vezes muito importantes, quea constância do título searrisca a encobrir". Perguntei-mesenão era preciso suprimir agora essa frase, poisela não émaisverdadei ra. M asacabei deixando, porque ela faz parte da história desse documento, ela é datada (ainda que, na data aqui indicada, já fosse obsoleta, ela remonta à primeiríssima edição, de 1984). D esse modo se percebe, primeiro, que nunca se faz uma bibliografia mecanicamente, isso não é posśvel (basta ver todas as estipulações consignadas na advertência, quealiás serviu de guia duranteo trabalho), e, a seguir, que ela tem uma vida própria. Veja que no começo eu fazia o inverso do que o senhor parece hoje preconizar: eu conservava unicamente a primeira menção e deixava de lado as republicações, para evitar o efeito da repeti ção. M as havia também uma justificação que aparece em retrospecto: a primei ra menção não tinha ainda claramente o estatuto de antecedente, muito pouco tempo havia transcorrido entre a primeira publicação e as seguintes, não se podia ainda dișingui-la como uma etapa em relação a uma fase ulterior, como um rascunho em relação a algo mais elaborado. Eu dava prioridadeà data maisantiga porquemepare cia de fato que, justamente, ela marcava data. Introduzi as republicações mais tarde, retrospectivamente, quando vi que, omitindo-as, eu punha de lado uma informação importante sobre a lógica do trabalho.

N a verdade, a principal virtude da lógica do "rascunho" é evitar o efeito de fechamento que certos textos muito trabalhados podem produzir. 0 
trabalho faz desaparecer os vestígios do trabalho, em proveito do definitivo, do acabado (os pintores pretensiosos sacrificaram com freqüência seus mais belos esboços a seu gosto professoral do acabado...). A revista Actes de la Recherche foi também concebida dentro da lógica do rascunho e ela serviu de tubo de ensaio à maioria dos textos que resultaram em meus livros $^{15}$. (É verdade que a revista não permaneceu estritamente fiel, ao longo dos anos, a seu projeto de origem, às vezes ela cedeu à pressão do meio...) Em suma, penso que uma leitura de boa-fé pode ensinar muito sobre a série dos textos sucessivos. Tenho um bom exemplo: escrevi três artigos sobre o Béarn [província do sudoeste da França], um primeiro em 19611962, "C elibato e condição camponesa"16, um segundo na revista Annales, "Estratégias matrimoniais"17, e um terceiro pouco depois, que se chamava "Reprodução interdita"18. Entre os três, há em realidade uma enorme mudança. É um pouco como se eu tivesse abordado três vezes o mesmo tema de concurso: "Explique por que os primogênitos, numa tradição de direito de primogenitura, se vêem surpreendentemente atingidos pelo celibato". $\mathrm{N}$ a verdade, respondo três vezes à mesma questão, de maneira sempre um pouco mais sistemática, mais verdadeira, graças a um novo trabal ho sobre os dados, as estatísticas... N esse caso, percebe-se bem que se trata de três artigos diferentes. N outros casos, sobretudo quando o título é o mesmo, a bibliografia pode fazer pensar que éo mesmo artigo citado três vezes, e dar armas às pessoas malévolas, principalmente quando a primeira edição foi assinada com mais alguém.

Esse é um problema que eu ia colocar. 0 fato de haver um co-autor é uma situação que com freqüência levou a dificuldades relacionais. 0 co-autor pensa que tem um texto indiviso com o senhor, e ele descobre que o texto tem vida própria. D aí também as frustrações, que são compreensíveis..

Sim enão. Porque, quase sempre, eu avisava queia reutilizá-lo, isso estava acertado. (Às vezes atésem dizer, quando era o caso - como nas pesquisas sobreas grandes escolas, quemobilizaram muita gente- deuma situação de aprendizagem por ocasião de um primeiro trabalho.) A assinatura de um primei ro estado de um trabalho era um modo de reconhecer uma certa participação num certo estado de um trabal ho coletivo. As retomadas dos artigos em livros não são simplesmente patchworks. $\mathrm{N}$ a maioria das vezes, foram trabalhos planejados que fiz por etapas. (É uma das maneiras de resolver a alternativa artigo ou livro, um problema para muitos pesqui sado-
15. Actes dela Recherche en Sciences Sociales veio à luz em janeiro de 1975. Seu número inaugural comportava um manifesto, reivindicando explicitamente o direito de publicar textos não definitivos.

16. “Célibat et condition paysanne", Études Rurales [1962].

17. “Les stratégies matrimoniales dans lesystèmede reproduction", Annales [1972].

18. "Reproduction interdite", Études Rurales [1989]. 
19. La N oblesse d'État. Grandes écoles et esprit de corps [1989].

20. Q uestions de sociologie [1980].

21. Langage et pouvoir symbolique[2001] éuma edição francesa, revistae aumentada, de Language and Symbolic Power [1991], que por sua vez era uma coletânea de textos traduzidos de $\mathrm{Ce}$ que parler veut dire [1982]. Assim, três edições sucessivas (de dez em dezanos) apresentam textos sobre o mesmo tema da linguagem. res: uma série de artigos ordenados de antemão compõe, por um trabalho que não é simples emenda, um verdadeiro livro. Esse é um conselho que dou seguidamente aos jovens pesquisadores: é preciso produzir peças, mas peças pensadas como elementos de um conjunto.) É o caso de La N oblesse d'É tat [A nobreza de Estado] ${ }^{19}$. Por esse procedimento chega-se a fazer construções de uma coerência e de uma complexidade impossíveis de alcançar pela simples redação sucessiva segundo um plano linear. Conseguese totalizar totalidades parciais já realizadas e publicadas (o que permite também contar com os benefícios da objetivação e das reações provocadas). Essa meta-construção muda completamente o sentido e a função dos elementos utilizados, os quais, além disso, são profundamente transformados no detal he de seu conteúdo. N as notas, costumo pôr "versão reelaborada", "versão modificada", "versão revista e corrigida"; às vezes mudo o título. $M$ as receio que essas indicações escapem muitas vezes ao leitor, e que possam pensar que conto semprea mesma coisa!

O senhor chegou a fazer também compilações. Retrospectivamente vemos as coisas se ordenarem. Em Q uestions de sociologi $e^{20}$, por exemplo, penso que imaginou essa compilação com um objetivo dlaramente pedagógico.

Sim, é o caso oposto de La N oblesse d'É tat, que era um livro planejado, organizado segundo um grande plano de conjunto (que sintetizava tudo 0 que eu havia feito desde os anos de 1970, no que se refere à educação). U m exemplo ainda mais significativo que $Q$ uestions de sociologie é $L$ angage et pouvoir symbolique [Linguagem e poder simbólico] (dever-seia dizer Language and Symbolic Power ${ }^{21}$ ): nesse caso, trata-se realmente de uma compilação - foi meu editor inglês, John Thompson, que a propôs. Ele havia traçado um plano geral e acrescentei alguns textos, tornei a acrescentar outros na última edição, e agora me digo ainda: que pena!, eu deveria ter posto isso e aquilo. Se puder, na próxima edição, vou ainda acrescentar dois ou três artigos. E, não obstante, esse é um livro, em minha opinião, muito coerente, certamente porque reúne textos que foram pensados no mesmo momento e dentro da mesma lógica.

Paradoxalmente, podese dizer que todas essas mudanças - de título, em particular - não facilitam a identificação das mudanças... $\mathrm{E}$, quando 0 senhor põe um novo título que afinal não é muito diferente, as pessoas se perguntam: por que será que ele mudou o título? Além disso, pode-seter a impressão do déjà vu. 
Sim, eu sei. O utra coisa que me irrita é que, por exemplo, escrevi dois artigos sobre a linguagem, que apareceram na revista... não lembro mais... uma revista de lingüistas...

D ecididamente, o senhor, tão preci so nas suas indicações bibliográficas!... Ainda bem que estamos aí!

É verdade, é verdade. Enfim, peguei esses dois artigos para fazer deles um livro. Comecei em junho, acabei em setembro. Trabalhei muito: acrescentei muito e reduzi outro tanto, a coisa se tornava mais e mais cerrada, mais densa, mais elíptica, mas também mais e mais coerente... Se me dizem: mas é o mesmo artigo, isso me deixa furioso. Evidentemente, para um leitor apressado, é sempre igual: "ele mostra que a linguagem depende das condições sociais da recepção". M as, se perceberem a articulação da demonstração, éo dia ea noite. Sefor retida apenas a conclusão, sem levar em conta a maneira de atingi-la, isto é, a lógica da demonstração, não se vêa diferença entre um discurso científico e uma profissão de fé qualquer, a qual pode chegar, por preconceito ou acaso, à mesma conclusão. Para quem se atém às linhas gerais, às "grandesidéias", ou seja, àquilo que o leitor apressado retém de uma obra complexa, não há nenhuma diferença entre L esH éritierse L a N oblessed'État, quando em realidade La N oblessed'État representa vinte anos de pesquisas e sobretudo um progresso imenso, uma mudança de "nível" inusitada, mas que só pode ser vista como tal por pessoas muito atentas emuito competentes, eque poderiam decerto modo têla efetuado. N ão há muitas assim...

H abitualmente, o senhor mesmo indica em nota, nos seus livros, onde foram publicados anteriormente os textos que retomou. $M$ as, em Les Règles de l'art [As regras da arte] ${ }^{22}$ e M éditations pascaliennes [M editações pascalianas] ${ }^{23}, 0$ senhor não o fez. Houve um certo embaraço para tratar essa "omissão": ela devia ser respeitada ou não? Era intencional de sua parte ou não? Em suma, teria ela um sentido particular? Num primeiro momento, pareceu-nos que sim, de modo que, em nossa bibliografia, o conteúdo desses dois livros não é dado em detalhe, para levar em conta sua suposta intenção (aliás, o senhor mesmo acaba de dar uma justificação plausível para isso). M as não etou mais tão certa de nossa interpretação: é posśvel também que, para o senhor, a correspondência entre o livro e os artigos anteriores (na revista Actes, sobretudo) seja tão evidente que nem pense mais em assinalá-la. Ainda mais que, no caso
22. Les Règles de l'art [1992].

23. M éditations pascaliennes [1997]. 
24. R. Q ueneau, Cent millemilliardsdepoèmes, 1961. A obra compõese de dez sonetos, cujos versos são defato intercambiáveis.
25. M. Weber, Wirtschaft und Gesellschaft, Tübingen, M ohr, 1922 (publicação póstuma, já que o autor morreu em 1920); tradução parcial em francês, Économieet sociééé, Paris, Plon, 1971. dos artigos da Actes, o senhor não está constrangi do pelo protocolo de cortesia que quer que sejam citados os locais de publicação anteriores, relativamente aos novos editores, uma vez que o senhor mesmo é o mestre-de-obras da Actes e concebeu essa revista precisamente para receber textos de percurso: talvez não se sinta no dever de ter que precisar isso em toda ocasião.

Sabe que é verdade? Agora que você me diz é que me dou conta de que esqueci deindicar... M as há uma coisa que tenho vontade de lhe dizer aqui sei que é uma confissão perigosa... - , é que há muito tenho, a propósito de minha obra, dois, talvez trêsfantasmas... 0 primeiro éfazer um livro infinito, segundo o modelo que Q ueneau inventou, "O s mil" ou "O s cem mil milhões de poemas" (ele escreveu sonetos, recortou-os em tiras, de tal maneira que cada verso pudesse ser combinado com todos os outros ${ }^{24}$ ), ou ainda um livro total, que contivesse a totalidade do que eu disse ou quetenho a dizer. M uitas vezes me aborreço ao escrever, porque me digo: aqui eu teria quetornar a dizer (ou tornar a demonstrar) algo quejá disse em outro livro. Eu teria necessidade, em cada um de meus livros, de todos os meus livros. I sso não é esnobismo. As pessoas costumam me dizer: mas por que faz referência a você mesmo? Elas acham que é complacência, narcisismo, sei lá. Em realidade é uma estenografia, para fazer as vezes de al go que não tenho tempo ou não tenho a força de lembrar ou de demonstrar (quando se está concentrado num problema, não se pode convocar tudo que está envolvido ou sugerido no que se disse e se estabeleceu noutra parte; as más leituras de meu trabalho vêm, em sua maioria, do fato deisolarem do conjunto essa ou aquela pesquisa, em função da divisão tradicional em especialidades).

E o segundo fantasma, se o conheço bem, é exatamente o oposto e mais ou menos a mesma coisa: um livro muito construído e controlado, que seria um livro total mais sistematicamente organizado...

Sim, éisso, o segundo fantasma éa idéia de apresentar todos os conhecimentos sob a forma perfeitamente dedutiva e linear de um Tractatus que desenrolaria - um pouco como fizemos em La Reproduction - a totalidade das proposições científicas estabelecidas. Com freqüência pensei, lendo W irtschaft und G esellschaft [Economia e sociedade] ${ }^{25}$, que essa é uma tentação perigosa à qual eu devia cuidar para não sucumbir. Em realidade (etalvez seja um efeito de minhas disposições "borboleteantes", como dizia Fourier, que me levam a sair em busca da descoberta de coisas novas em vez 
de concentrar-me na elaboração formal das coisas adquiridas), nunca pude resignar-me a tentar oferecer uma apresentação global de meu trabalho. Se o fizesse, eu teria a impressão de me entregar a um exercício escolar ou, como diz Q ueneau, que também não gostava muito dos professores, de me "manualizar", de virar eu mesmo um manual. 0 fato é que a ausência de um pequeno Bourdieu "manualizado" ou "manualizável" não facilita a difusão de meu pensamento nas "escolas"... e principalmente no estrangeiro. $M$ as também aqui não estou certo de lamentar esse fato. $\mathrm{H}$ á pessoas que, pela mesma razão, compreendem que minha "obra" é ao mesmo tempo coerente, talvez mesmo sistemática (não vejo, digam o que disserem os "pósmodernos", o que há de mal nisso, quando se trata de ciência...), e aberta, e isso porque o quetenho a transmitir éantes de tudo um "ofício", um modus operandi que está presenteem cada uma das peças do meu trabal ho (há uma belíssima tirada de Rogers Brubaker que, quando o ouvi por ocasião de um colóquio em Chicago dedicado ao meu trabalho, produziu-me um efeito de revelação $\left.{ }^{26}\right)$. E é esse "ofício", aplicado a novos objetos dos quais nunca tratei, que permite (a mim ea outros) produzir análises conformes ao projeto ou ao "programa". N o fundo se reconhece o fantasma dos mil milhões de poemas (que, diga-se de passagem, éum fantasma deerudito, o da "combinatória universal", não étão descabelado assim!).

O uvi muitas vezes o senhor dizer que seria preciso, para ser justo com seus colaboradores, fazer como no cinema e apresentar, quando oportuno, os créditos na abertura das produções. Por que não o fez? $\mathrm{N}$ ão, o que estou dizendo é falso: 0 senhor o fez pelo menos duas vezes, em L'Amour del'art e, muito mais tarde, em La N oblesse d'État. N o prefácio de L'Amour de l'art, o senhor fala precisamente de "créditos", e de fato os oferece até nos menores detalhes técni$\cos ^{27}$. No final, eles se confundem um pouco com os agradecimentos obrigatórios às altas personalidades que autorizaram a entrada nos museus, mas as personalidades vêm de todo modo depois dos colaboradores. Em La N oblesse d'État os "créditos" etão muito mais integrados no livro, são portanto menos ostentatórios emenos viśveis, fazem parte de um anexo metodológico (na parte dedicada às grandes escolas), percebese que o senhor tem o cuidado de explicar, de fazer uma ligação entre a organização completamente aberta dessa investigação e as exi gências do empreendimento ci entífico, que o senhor queria preservar das pressões institucionai ${ }^{28}$. São créditos que não dizem realmente seu nome, explicam um procedimento de pesquisa ao mesmo tempo que apre sentam as pessoas. Por que não fez isso de maneira mais geral?
26. R. Brubaker, "Social Theory as H abitus" (Chicago, 1989), em C. Calhoun, E. LiPuma, M. Postone(eds.), Bourdieu: Critical perspectives, C ambridge, Polity Press, 1993, pp. 212234.

27. "Avant-propos", L'Amour de l'art [2 ed. 1969], pp. 7-9.

28. La N oblesse d'État. Grandes écoles et esprit decorps [1989], Anexo 2, "La méthode", espe cialmentepp. 336-337. 
Porque nem sempre há oportunidade. E porque teria sido necessário criar integralmente o modelo. É verdade que isso permitiria mostrar exatamente quem fez 0 quê. M as seria necessário criar tudo, em particular as palavras para definir as diferentes funções e a divisão do trabalho correspondente. Sim, eu era de fato o diretor, o metteur en scène (para o conjunto das pesquisas do $C$ entro, individuais ou coletivas): eu tinha a idéia inicial, produzia o questionário ou o roteiro da entrevista, realizava um certo número de entrevistas preliminares, estabelecia o código, intervinha em todas as fases da produção, na codificação, na análise estatística etc. M as a função, e mesmo a designação das tarefas dos que puderam participar desse trabalho, simplesmente não é algo instituído. Esse é um problema que se coloca em todas as ciências, nas ciências da natureza é a mesma coisa, eles põem quinze assinaturas. Elas devem aparecer em ordem alfabética ou não? H ouve um monte de estudos a respeito: quando um prêmio $\mathrm{N}$ obel assina, ele não aparece em primeiro lugar, mas em realidade é ele, por ser 0 mais conhecido, que dobra ainda mais a aposta, já que é modesto e não se coloca à frente. Esse é um verdadeiro problema, não resolvido, na pesquisa. M as tampouco no cinema é simples.

Sim, mas no cinema há pelo menos funções, tarefas bem delimitadas. há um i luminador, um operador de câmera, um rotei rista, um sonoplasta, um montador etc., e essas pessoas têm uma certa autonomia, é posśvel seguir o itinerário de um rotei rista, que trabal ha com fulano, depois com sicrano, enquanto aqui, quando setrabal ha numa equipe, éproblemático levar suas competênciasa outra parte, isso não sefaz.

As tarefas não são bastante diferenciadas, não se pode ser codificador como se é operador de câmera ou montador.

Sim, é difícil designar lugares às pessoas.

O único possível seria o de estatístico, e olhe lá... Tudo depende de qual estatístico e de que tipo de estatística... Você tem razão, a coisa, entre nós, não tem nome, não está codificada, e, de fato, não se pode ir de uma equipe a outra, pegar sua trouxa e partir; ou então adquire o aspecto dramático de uma ruptura... D epois, outro obstáculo é que essas tarefas são hierarquizadas. E terrivelmente. Com isso, muitas vezes, dizer de alguém o que ele realmente fez é esmagá-lo. Ao mesmo tempo percebi com freqüência que, 
em certos momentos, uma pequena intervenção, mínima e quase não articulada, me evitou um erro. M as como fazer que isso apareça? D o mesmo modo, inversamente, um mau codificador pode destruir uma pesquisa.

Sim, mas há também tarefas intermediárias. Q ual é o estatuto daquele que, por exemplo, discute com o senhor ao telefone?

U ma coisa que levei muito tempo para compreender é que freqüentemente invento ao falar. $\mathrm{N}$ ão, é claro, com qualquer um. É preciso um interlocutor...

0 senhor inventa ao falar, é verdade, acho que já sabia di $5 s 0$ antes de 0 ter formulado claramente. 0 senhor dizia sempre, ao falar, "vocês notaram?", "isso é i mportante, observem bem", mas logo percebi que nunca se devia, mes mo a pedido expresso, colocar-Ihe sob o nariz as anotações feitas durante essas conversas. Podia-se voltar ao assunto oralmente, e retomar a di scussão, mas 0 senhor sempre ficava decepcionado com as notas manuscritas. "eu disse mais do que isso!", "você etá certa que é só isso?", "tenho a lembrança de outra coisa"; em realidade, nas anotações não havia mais a efervescência, a alegria e até mesmo a emoção de avançar, era como cerveja choca. Em todo caso, o papel do interlocutor, enquanto estimulante, é um elemento importante...

Sim, absolutamente. Se disséssemos: esse trabalho não teria sido o que ele é sem fulano ou sicrano, a lista seria longa... E pensei muitas vezes, nas ocasiões solenes, como uma aula inaugural ou uma entrega de medal ha, em enumerar todas as minhas dívidas; mas como fazêlo sem omitir ninguém e ponderando com justiça as contribuições, sob o aspecto da qualidade e da quantidade? Renunciei sempre, arrasado só de pensar antecipadamente nas injustiçasinevitáveis e nas insatisfações que eu não deixaria de suscitar. Esse éum problema insolúvel, mas penso que se deve em parte ao fato de a divisão do trabalho não ser clara, de as tarefas serem tremendamente hierarquizadas, em nome de uma hierarquia que passei a vida inteira a contestar, a do empírico e do teórico, em particular. 0 ra, tudo isso é muito difícil de levar em conta nos créditos.

Será quenão écontraditório dizer quea di visão do trabalho éao mesmo tempo frouxa emuito hierarquizada?É como reconhecer que o méo ébastante diabólico, nunca se sabe exatamente quem seé, e no entanto isso édeterminante. 
Sim, essa confusão é que permite todos os jogos da mentira a si mesmo e da má-fé, sobretudo a propósito das contribuições respectivas, que diferenças mais marcadas e hierarquias mais afirmadas tornariam mais difíceis, talvez até impossíveis.

$M$ as o sentimento de que os textos Ihe pertencem como al go próprio, mesmo que na origem tenha havido co-autoria, será que se deve ao fato de o senhor se encarregar sempre da redação final, que representa uma etapa decisiva da produção?

É isso, mas também muito mais que isso. É o metteur en scène! É o fato de a idéia inicial ser minha, de eu ter dado todos os impulsos importantes em todos os níveis da pesquisa, no nível da codificação, mas também no da análise estatística.

M as o que significa então, para o senhor, assinar com mais alguém? D ar-Ihe a possibilidade da co-autoria e de associá-lo assim oficialmente, visivelmente, a seu trabalho?

Isso varia, depende muito das situações. Já me aconteceu, não vou dar nenhum exemplo preciso, de "pagar" alguém por um trabalho que havia feito comigo em outra pesquisa, fazendo-o assinar uma pesquisa da qual não participou em absoluto. Como sempre fui marginal nas instituições às quais pertenci - quero dizer, sem poder temporal nessas instituições - , e como eu não podia pagar as pessoas financeiramente, e sobretudo academicamente, oferecendo cargos, então eu pagava com assinaturas. Penso que eu deveria ter sido mais prudente, por inúmeras razões e sobretudo, talvez, porque há presentes envenenados. Foi o que compreendeu muito bem um rapaz que fez comigo um primeiro trabalho de aprendizagem e que me disse em seguida: não quero assinar com o senhor, eu não poderia escrever mais nada depois... U ma assinatura é terrível, envolve coisas muito profundas, ligadas à identidade. Pensei que eu fosse capaz de dominar essa dimensão das relações de colaboração, para mim e para os outros, pelo raciocínio, pela análise, explicando.

0 senhor não apenas administrou sua própria assinatura, mas as de todo 0 Centro. O rganizava a divisão do trabalho e a distribuição das tarefas, dizia: "Isto vocês assinarão juntos"... 
Eu fazia isso em função da idéia que tinha da justa repartição das contribuições e das "partes" que era lícito reconhecer a cada um...

Convém dizer que essa idéia de equilíbrio do mundo ia bem mais longe: no interior do grupo, o senhor freqüentemente associou, num trabal ho de pesquisa específica, pessoas que o peso das realidades sociais teria separado na vida normal. Penso na equipeque diversas vezes formei com $M$ oniquedeSaint $M$ artin: dificilmente sepodeimaginar uma dupla maisbizarra, no entanto trabalhávamos, e com bastante eficácia, mastambém com constrangimento. Acho que nos desestabilizávamos mutuamente.

Sim, subestimei as dificuldades, sobretudo psicológicas, e superestimei meu poder de resolvêlas, pela sociologia ou a socioanálise. Subestimei também os efeitos do tempo e do envelhecimento social diferente dos diversos membros do grupo. Pequei por uma espécie de desmedida, que era também a contrapartida do meu investimento, imenso e certamente um pouco desvairado, na tarefa, esmagadora, que era animar, inspirar ou orquestrar o grupo. Pensei que tudo poderia se administrar racionalmente, e foi o que aconteceu a maior parte do tempo no movimento da pesquisa. Porque não se deve ver as coisas separadamente, mas no movimento de toda uma vida de pesquisa.

Sim, é retrospectivamente que se percebe nisso tudo coisas confusas. No momento, no movimento da pesquisa como o senhor diz, tínhamos o sentimento de uma partilha, que talvez não fosse eqüitativa a cada instante mas que se compensaria necessariamente no tempo. Pensávamos que não nos de xaríamos jamais. Lembro uma viagem de carro que fiz num fim de semana, eu voltava do Norte, chovia, fazia frio e começava a escurecer, a auto-estrada estava cheia, e apesar de tudo eu tinha um sentimento feliz, não sabia por quê, antecipava algo que em breve me daria prazer mas não sabia exatamente 0 que era, e então de repente eu soube, era a idéia de que íamos todos nos rever na segunda-féra de manhã. H á um filmeitaliano deEttore Scola, chamado $\mathrm{N}$ ós que nos amávamos tanto, que sempre me comove um pouco, por causa de seu título e de seu tema, um pequeno grupo político cujos membros envelheceram e se dispersaram... sinto muita nostalgia.

Sim, nem tudo sempre se passa como se poderia acreditar que passaria; os destinos divergem e, com o tempo, as coisas mudam de sentido. Um 
pouco talvez porque, como pude compreender ao estudar a evolução dos impressionistas, o grupo unido no período inicial, o das dúvidas e dos combates, se divide quando chegam os primeiros sinais de reconhecimento, que fazem desaparecer uma das bases da solidariedade e que não se distribuem de maneira igual. M as é muito mais complicado que isso. Sobretudo, é toda uma libido que é investida na pesquisa, são a idéia e a imagem de si, coisas muito poderosas, em todo caso. Conto apenas esta anedota, sobre um sujeito que ainda vejo: eu estava em meu escritório no bulevar Raspail, ele vem me ver, falo com ele, dou-lhe uma idéia. Ele vai embora, depois retorna (estava três portas adiante), e diz: Acabo de ter uma idéia formidável! Era exatamente a que eu acabara de Ihe dar. D urante um segundo, pensei comigo: 0 que faço? digo a ele? Porque não é simples, a gente está diante de um delírio. Será que digo a ele ou não digo nada? Eu não disse nada.

Essa anedota diz algo mais. 0 senhor disse dou-Ihe uma idéa, mas uma idéa não é uma coisa material, que se pode dar ou receber sem preâmbulo, sem preparação. Essa idéa vinha do seu pensamento do momento, era preciso que ela levasse o tempo de se incorporar no pensamento do outro. Foi talvez somente isso que aconteceu com o sujeito de sua anedota. Essa espécie de adaptação diferida sucedeu-me diversas vezes em sua presença, o senhor fala depressa, as palavras se empurram na entrada, o senhor diz "etc.", "percebem?", corta a resposta para prosseguir sua idéia, com frases que deixam no ar um "não?" interrogati vo que não espera a resposta, anedotas mal contadas por serem muito precipitadas... Eu me dizia com freqüência: compreenderei mais tarde. Porém mais tarde a idéia está tão irreconhecível, porque foi amassada mentalmente, que com toda a boa-fé não se sabe mais de onde ela vem. 0 que é surpreendente na história do seu sujeito não é a apropriação inconsciente que ele fez da idéia que o senhor Ihe passou um pouco antes, é que ele venha Ihe dizer, o que revela muito sobre o poder de legitimação que o senhor possui.

Sim, éuma coisa muito estranha: as pessoas sabem enão sabem. Sabem e não querem saber. É um verdadeiro problema, muito difícil, cuja dificuldade eu subestimei. D e um modo geral, subestimei tudo isso.

Li muito recentemente o trabalho de um historiador que mostra que o proble ma não é novo. É no último número da Annales, em que se acha reproduzida uma controvérsia relativa ao direito de propriedade sobre os bens culturais. 
Essa controvérsia diz respeito ao direito medieval, mas podese transpô-la. Em todo caso, os argumentos apresentados me fizeram refletir. A quem pertence uma obra, quando ela resulta da transformação que fazemos de um suporte que, no caso, não nos pertence? U ns dizem que, sea transformação éirreverśvel, isto é, se o objeto não pode mais retornar à sua forma inicial, então o autor da transformação é que é o proprietário da obra. O utros assinalam diferenças, considerando a maneira como a modificação se integra ou não com a forma primeira: será que há continuidade de um etági o a outro (e, nesse caso, o detentor do objeto inicial permaneceria proprietário do todo) ou descontinuidade (o que supõe que se possa distinguir a parte acrescentada)? Penso que é exatamente esse 0 tipo de questão que se pode colocar a propósito das produções que foram inicialmente de co-autoria, antes de serem retrabalhadas e assumidas apenas pelo senhor.

$M$ as você esqueceque o trabal ho de co-autoria continua existindo como tal e pertence aos dois signatários. Eles podem citá-lo em suas bibliografias, e o fazem. N unca vi inconveniente nisso. Pelo contrário: em meu espírito era essa a regra do jogo. Por outro lado, os desenvolvimentos ulteriores das obras respectivas, enão apenas as republicações, dão uma idéia do que haviam sido as contribuiç̧̃es efetivas.

$\mathrm{N}$ ão, isso é uma prova a posteriori que não quer dizer grande coisa. Ao dizer isso, o senhor se coloca na mesma ótica anacrônica dos que vêem, retrospectivamente, nos arranjos entre co-autores de um momento, cálculos que explicam um estado de coisas bem posterior. Se o passado não pode testemunhar o pre sente, o inverso tampouco é possível. Tendo os destinos divergido, as condições de produção, antes e depois, se tornaram incomparáveis, a produtividade intelectual se mede de outro modo, os interesses mudam de natureza, nada se pode deduzir daí. N ão se pode negar que a pertença a um grupo muito coeso protege contra a inércia do mundo secular, e portanto favorece o projeto intelectual. Perder o grupo é perder muito mais do que um lugar de sociabilidade, onde se formaram hábitos e se deixam necessariamente vínculos, é tornar-se, ademais, muito vulnerável e diretamente responsável pelos resultados. 0 programa inte lectual sofre claramente com i sso. N ão, não se pode deduzir nada dos destinos intelectuais de cada um, somente a partir dos velhos manuscritos é que se pode restabelecer as contribuições dos diferentes redatores. E foi justamente porque vi a maior parte dos manuscritos, no tempo em que foram escritos, que liguei essa questão principalmente à escrita. 
29. P. Encrevé, Soulages I'oeuvrecomple: peintures, Paris, Éditions du Seuil, 3 vols., 1994, 1995, 1998, 1000 pp., com acréscimos e correções.

30. R. Vailland, Comment travaillePierreSoulages, Pantin, Le Temps des Cerises (coleção CahiersRoger-Vailland), 1998.
D eixemos isso de lado... Convém deixar isso para os arquivos e os arquivistas.

0 trabalho dearquivamento, sim, elemefaz pensar no trabal ho de catalogação feito sobre a obra de Soulages e que regi stra, para cada um de seus quadros, 0 i tinerário das obras desde o momento em que são postasno mercado ${ }^{29}$ : éa circulação da obra que évalorizada, a obra em si não muda ao longo dasaquisi ções. Por que se acha normal, e mesmo prestigioso, fazer isso em relação aos quadros, e por que ninguém se contenta em fazer o mesmo em relação aos textos escritos? Por que é preciso dar justificações para isso? A dmitese impli itamente que um quadro é desde o início definitivo, mastalvez esteja aí a ilusão. Li um pequeno livro de Roger Vailland, chama-se Comment travaille Pierre Soulages [A maneira de trabalhar dePierre Soulages] ${ }^{30}$ : éuma sessão detrabal ho observada por Vailland, que relata como Soulages executa um quadro preto diante dele, em seu ateliê, como ele passa por tons nacarados, ocres, por gestose movimentos oblíquos, no final Vailland data o quadro, foi feito em março de 1961, mas, diz Vailland, ele só adqui rirá todo o seu sentido retrospectivamente, consi derando a totalidade da obra de Soulages. A descrição feita por Vailland dessa sessão (écurta, umas vinte pági nas, nem isso) foi uma surpresa para mim, eu não imaginava toda essa energia, não sabia que o preto não era preto, materialmente. Então des cubro, também, que o que falta a essa bibliografia éum discurso de acompanhamento, porque, se qui serem ter uma imagem justa do trabalho que o senhor produziu, é preciso conhecer sua maneira de trabalhar, ter visto seus manuscritos cheios de emendas, colados com durex, o texto torcido em todas as direções, com balões intermináveis rabiscados nos cantos, flechas, acréscimos, garatujas..

Ainda hoje, nessas velhas garatujas, redescubro as pequenas marcas que você pôs...

Se não se tiver isso em mente, a gente deixará impor-se, sem querer, o que há sempre de retilíneo e de redutor numa bibliografia, mesmo quando ela apre senta muitas circunvoluções, como aqui. Eu mesma, quando vi os últimos desdobramentos dessa bibliografia, tive a impressão de uma vasta organização, com "honoráveis correspondentes" um pouco em toda parte, em Atenas, Tóquio, Estocolmo, Constança, Cambridge, Londres, sem esquecer o Brasil, o Canadá, que se mobilizam instantaneamente assim que o senhor publica um texto, e paf!, no mesmo ano está traduzido em toda parte. E eu achava que com essa perspectiva elevada sobre sua carreira o senhor se expunha muito. Em 
realidade, como me disse $\mathrm{M}$ arie $C$ hristine Rivière, continua tão anárquico quanto antes Como traduzir isso numa bibliografia? No começo, paralelamente a esse trabalho, eu relatava o que havia por trás e tudo o que não era dito, mas esse empreendimento foi abandonado.

Considera-senormal contar como Soulages trabalha porque se tem uma visão hagiográfica, que está ligada à representação carismática do trabalho do pintor. Aliás, é tamanha a fetichização de cada obra, certamente para os próprios pintores, que é raro eles retomarem uma obra já exibida para retrabalhá-la.

No caso de Soulages, o trabalho de reconstituição é particularmente precioso. Porque a elaboração de sua obra não deixa nenhum traço: ele mistura cores, nácares, trabalha toda uma jornada, como um condenado, e finalmente se vê um quadro preto. M as, no que concerne ao senhor, os traços estão aí, há estági os anteriores. por que se abster de mostrá-los?

$\mathrm{N}$ a verdade, isso não me incomoda tanto assim. Exceto, talvez, porque se pensa em tudo ou nada, e não se sabe dar seu verdadeiro estatuto a esses traços. 0 u se dá a eles o estatuto de artigo definitivo, ou se lhes concede absolutamente nada. Veja, quando foi feita a edição de M auss, deK arady ${ }^{31}$, havia coisas muito diferentes, grandes textos, apostilas, resenhas, transcrições de intervenções orais etc. Trata-se de alguém que praticamente não escreveu livro, escreveu apenas artigos. M esmo o E ssai sur le don [Ensaio sobre a dádiva] ${ }^{32}$, penso que é uma reconstrução ex post facto. $\mathrm{O} u$ se faz como se cada traço fosse um opus, uma obra acabada, ou então como se fosse apenas um primeiro jato, que pode ser deixado lá onde está, no sótão das revistas obscuras que ninguém lerá mais. É um pouco o que fez LéviStrauss, que consagrou a M auss um volume de textos por muito tempo considerado definitivo ${ }^{33}$, antes de exumarmos mais três grossos volumes depois dele: decidiu-se colocar, ao lado dos "grandes textos", conjuntos intitulados "textos de apoio" que dão uma idéia do canteiro de obras no qual M auss foi buscar materiais, como os talhadores de pedra medievais que recorriam às ruínas antigas. No que se refere a mim, há, entre um texto oral e sua retomada num livro, às vezes quinze versões. $\mathrm{E}$ a cada vez acredito que acabou... Aliás, quando quero realmente que esteja acabado, eu digo: não me mostrem mais, porque não posso me impedir de modificar. E não somente a escrita, porque nesse meio tempo trabalho, e progrido.
31. M. Mauss, O euvres, Paris, ÉditionsdeM inuit (coleção Le sens commun), 3 vols, 1968-1969 (com apresentação deV. Karady).

32. M . M auss, Essai sur le don, forme archaïque del'échange, Paris, 1925.

33. M . M auss, Sociologie et anthropologie, precedido deumaintrodução à obra deM arcel $M$ auss por C. Lévi-Strauss, Pariș, PU F (coleção Bibliothèque de sociologie contemporaine), 1950 (mesmo ano da morte de M. M auss). A obra foi reeditada várias ve- 
zes, especialmente em 1966, pouco antes do lançamento dosvolumes deM auss pelaÉditions de M inuit.
34. "La délégation et le fétichisme politique", Actes de la Rechercheen SciencesSociales[1984].
O utra coisa que o incomodou nessa bibliografia, acredito, é o fato de se ter feito uma categoria à parte com suas intervenções orais, marcadas pela indicação de um local e de uma data. N ão, não é exatamente a existência dessa categoria que Ihe causava problema, éque ela tenha se tornado muito volumosa ao longo dos anos. Eu mesma fiquei impressionada quando revi a bibliografia. É algo que o aborrecia, talvez por um preconceito de que pudesse Ihe prejudicar, e segundo o qual falar é mais fútil e mais mundano do que escrever. E há comunicações orais, o senhor dizia, que são verdadeiros artigos. Resisti a seus argumentos porque, em primeiro lugar, penso que o senhor é também um professor ao mesmo tempo que um pesquisador, e porque tem uma missão pedagógica que para mim é mui to importante e condiz com a palavra falada. D epois, porque se trata muitas vezes de temas cujo aparecimento não se compreende bem se não se sabe que esão ligados a um contexto.

Sim, há intervenções que se ligam a um momento, a uma situação, às vezes a pessoas, à pessoa que me convidou.

Indica-se um local e uma data, mas isso não revela grande coisa, a não ser que é uma produção circunstancial, o que tem sua importância.

É verdade. Penso numa palestra quefiz a convite de PierreE ncrevé, para estudantes protestantes. É importante porque, na verdade, o assunto mesmo édeterminado por isso. $N$ a época, eu tinha uma preocupação na cabeça, a noção de delegação política etc. M as foi divertido colocar o problema num local religioso e protestante. $\mathrm{H}$ á todo um lado do texto (meio provocativo, para irritar, como o problema do ministério, do pastor, os textos de Kant ou de $\mathrm{N}$ ietzsche sobre o pastor, sobre a hipocrisia do porta-voz etc.) que estava ligado a esse contexto ${ }^{34}$. E geralmenteisso éimportante porquecomo compreendi depois - se trata, na base, de uma conseqüência de meu mau caráter, de meu lado malicioso, gosto de curtir ou cutucar um pouco 0 público, dizer-Ihe coisas que se arriscam a tocá-lo pessoalmente, para que a sociologia surta efeito, não seja uma simples alocução escolar. Penso numa palestra - não sei se entrou na bibliografia - que fiz para Vie nouvelle, um movimento de cristãos de esquerda, de casais muito certinhos; aquilo os excitou muito, fiz uma espécie de paródia do discurso católico. Em casos como esse, éverdade queuma parte do interesse do discurso (e portanto do texto) deve-seà ocasião na qual foi produzido. 
Esse lado provocativo, no oral, é também uma boa técnica de captação...

Sim, certamente, mas um pouco paradoxal, e em todo caso psicologicamente muito custosa, porque, se o público não fica indiferente, há o perigo de provocar reações violentas, de ser atacado, e várias vezes saí muito chateado desse tipo de experiência.

Baudelaire fala do "prazer aristocrático de desagradar": não penso que se aplique ao senhor! M as nem sempre suas intervenções são desse tipo, isto é, intervenções no sentido estrito, "ações", como diriam os artistas, ou mesmo happe nings. 0 senhor faz também intervenções clássicas.

Sim, à medida que avancei em idade, descobri que o tempo entre o momento em que concebia uma pesquisa e o momento em que podia escrevê la não cessava de aumentar - em razão, entre outras coisas, do aumento das tarefas diversas que me absorviam cada vez mais - , a ponto de eu temer às vezes nunca encontrar o tempo de publicar pesquisas importantes quefazia. Por isso tentei servir-me das intervenções orais, mas muito preparadas, muito elaboradas, para conservar um vestígio dessas pesquisas em andamento. H á um exemplo típico. Fiz no Collège[deFrance] um curso de dois anos sobre o Estado, que me exigiu muito trabalho, muita leitura, edepois fui obrigado a fazer outro curso sobre outro tema, tive que passar a outra coisa. D isse a mim mesmo que, se quisesse que restasse al go desse trabal ho, era preciso absolutamente inseri-lo em meu programa de intervenções orais. (Talvez por considerar que o trabalho intelectual éum trabalho como os outros, que não se deve de modo al gum fetichizar, sempre refleti prática e sociologicamente sobre as técnicas do trabal ho intelectual e, mais precisamente, sobre a melhor maneira de organizar meu trabalho a fim de tentar obter seu melhor rendimento.) H avia na época uma empresa universitária que queria fazer cursos filmados e, como eu ia falar em Amsterdã, sugeri que essa equipe de Strasbourg fosse para lá, onde eu faria um curso que poderia ser gravado. E esse curso foi pensado como uma espécie de síntese do meu curso no Collège. É só uma pequena parte, muito se perdeu; mas, vendo as pilhas de documentos em minhas estantes, digo-meque, pelo menos, resta esse curso ${ }^{35}$. Fiz isso várias vezes.

Falávamos há pouco do problema da passagem do oral ao escrito...
35. "Esprits d'É tat" (Amsterdã, 1991), Actes dela Rechercheen Sciences Sociales [1993]. 
36. Science dela science et réflexivité [2001].
D escobri, muito tardiamente, que esquecia minhas próprias idéias. Eu tinha a noção ingênua de que a gente não esquece as próprias idéias, mas muito freqüentemente redescubro velhos papéis rabiscados e me digo que, se não fosse a minha letra, eu não saberia que é meu. Por isso, para fixar coisas que me parecem importantes num momento dado, faço intervenções orais, improvisadas - raramente são textos lidos, a não ser quando vou aos Estados U nidos, ou em situações solenes - , mas segundo um plano muito detalhado, que conservo. 0 texto final, publicado, é o produto da integração de minhas anotações e da transcrição a partir do oral. E assim acabo fazendo textos às vezes melhores do que um que eu tivesse escrito diretamente. Penso que al guns textos vindos do oral têm a robustez e a precisão de um texto escrito (resultantes do plano preestabelecido e das anotações que reintroduzi), e ao mesmo tempo os achados, a flexibilidade, as transições que vêm da improvisação. D ei-me conta disso ao trabalhar na transcrição de meu curso sobre a ciência ${ }^{36:}$ no oral, diante de quinhentas pessoas, não se pode passar de uma idéia a outra sem fazer uma ligação (a menos que se use o expediente de certos professores, marcando: ponto a, ponto b). A mobilização é enorme - e fatigante - , a gente faz transições que, sozinho, diante da folha de papel, jamais teria encontrado...

Em todo caso, o senhor não gosta que se publiquem coisas vindas do oral sem que as tenha revisado.

Q uando me irrito contra a inscrição em minha bibliografia de alguns textos brutos, não é por uma questão de censura ou de imprimatur, mas porque a transcrição exata pode não fazer justiça, em sua exatidão mesma, à intenção, ao espírito do que foi dito. $\mathrm{H}$ á um caso que me incomodou, eu tinha ido a Londres, numa instituição cujo nome sempre esqueço, uma instituição esnobe, e fiz um diálogo com Terry Eagleton.

37. "D oxa and Common Life", New Left Review [1992].

\section{Sim, ele etá catalogado na bibliografia ${ }^{37}$.}

Está? Bem, eu o vi um dia mencionado numa bibliografia de tese e aquilo me aborreceu muito. Fiquei muito intimidado, era em inglês: 0 que é que eu disse, o que é que eu não disse? Eles publicam do jeito que está... Aquilo me irritou tanto que nunca quis lêlo, eu tremia de pensar no que ia encontrar. M as é um caso extremo. G eralmente, sobretudo agora, as pessoas não ousam mais; mas no início... 
Lamento que ele esteja catalogado, porque o ponto de partida da bibliografia era, de fato, mencionar apenas coisas publicadas mas assumidas pelo senhor.

Sim, mas "assumido por mim" não quer dizer, como se tende a pensar, que entendo exercer uma censura, dando ou recusando o imprimatur. $N$ ão, há critérios: em primeiro lugar, é meu ou não é meu; em segundo, é meu e transcrito corretamente, sem deformações, estilísticas sobretudo - tenho horror do falso oral vulgar, de má dissertação, que me atribuem com freqüência os entrevistadores, mesmo de alto vôo: penso numa entrevista publicada no $\mathrm{M}$ agazine Littérair $\mathrm{r}^{38}$ e que não ousei corrigir tanto quanto deveria (as pessoas transcrevem muitas vezes não o que eu disse, e que é talvez, à primeira vista pelo menos, um pouco despropositado, mas o que elas entenderam, e, apesar de minhas recomendações - peço sempre a estrita literalidade -, acreditam fazer bem em me corrigir); e, enfim, se for traduzido, que seja bem traduzido. $\mathrm{H}$ á coisas que circulam antes da revisão, isto é, antes desse trabalho de ajustamento.

A maneira como o senhor fala não é alheia à reputação que Ihe deram. Segui cursos de Thuillier, por exemplo, e ele diz numa hora o que o senhor diz em cinco minutos, éextremamentediluído, émuito civilizado... Já o senhor não dá em absoluto essa impressão, com suas frases não terminadas, os "etc." , os parênteses, sem falar também no seu vocabulário, sempre um pouco hiperbólico.

U m sujeito me disse algo assim, um dia, em N euchâtel, onde fui fazer uma pal estra sobre os ritos de passagem. A situação era um pouco paradoxal: há muito eu tinha a idéia de que a noção de rito de passagem era uma babaquice (a palavra é um pouco forte, mas é uma maneira de falar...). Fui então a um lugar, na Suíça, onde um autor muito famoso era celebrado (e de quem aprecio muito, aliás, os trabalhos de etnografia, sobre a França ea África do N orte) a propósito de um grande conceito, a noção de rito de passagem, e eu devia dizer que ela não funcionava de modo al gum, sem ser ofensivo nem injurioso, e sem reduzi-la, sem querer reduzir meu próprio conceito. M as ao mesmo tempo - eu vivia desse jeito - achava que tinha o dever, diante de pessoas cuja estima era importante para mim, como os Centlivres [Pierre e M icheline Centlivres, etnólogos suíços], Luc de H eusch [etnólogo belga] etc., de dizer o que pensava (em minha vida, fiz muitas intervenções dessa espécie, que se podem atribuir à cólera, ou à arrogância,
38. "Tout est social", M agazine Littéraire [1992]. 
39. “Les rites d'instituition", Actesdela Recherche en Sciences Sociales [1982].

e que se impunham a mim como um dever, geralmente muito difícil de cumprir, muito custoso psicologicamente). O s ritos de passagem são um conceito ingenuamente descritivo (a idéia de passagem evoca uma sucessão de momentos) que bloqueia a compreensão, em suma, é um obstáculo epistemológico da pior espécie, posto que erudito e consagrado pela tradição científica. Q ue fazer? Era um problema de retórica. Fiz uma apresentação ultra-rápida, creio que nunca falei tão depressa, com todo o tipo de silêncios (que os pontos de reticências traduzem mal), frases deliberadamente não concluídas, para deixar ao ouvinte a tarefa de concluí-las, e portanto de se dizer e pensar as coisas que eu não queria/podia dizer, gracejos acadêmicos (foi lá que me ocorreu a história de Schopenhauer sobre o cavalo de teatro que caga no palco, que fez todos rirem), palavras latinas e palavras gregas, é claro, e efeitos etimológicos, que fazem passar as coisas mais duras, como se fazia nos textos eruditos de outrora, em que eram ditas indecências em latim etc. etc., não faltou nada ${ }^{39}$ ! Pois bem, o tal sujeito me disse: Agora compreendo suas frases longas, porque o senhor fala muito depressa, com mudanças de tom, de ritmo, de tempo, parênteses que se abrem e se fecham três minutos mais adiante, exemplos esboçados; ao ouvi-lo, a gente compreende suas frases longas. Paradoxalmente, é uma retórica oral que faz compreender um texto que tem um aspecto realmente muito escrito, às vezes demais. $M$ as, ao mesmo tempo, há freqüentemente muita violência. Em realidade, essa retórica aparentemente desordenada, desenfreada, está aí para fazêla passar, e aceitar. No caso em questão, eu estava diante de pessoas que vinham celebrar o culto do rito de passagem, e ninguém ficou ofendido por meu discurso.

40. H omo academicus H omo academicus, por exempl $0^{40}$, não é um livro polêmico, no tom, mas é [1984]. um livro violento.

Sim, eu acho - e também para mim, contra mim.

$\mathrm{N}$ a verdade, foi o que me impediu de aceitar a co-autoria com 0 senhor, conforme me pediu. Porque não corresponde de modo algum a meu modo de ser, eu não teria podido assumir. Achava a forma muito masculina.

0 que não a impediria de ter assinado. Porque é um livro violento mas, ao mesmo tempo, muito controlado. 
$\mathrm{N}$ ão digo que não era, ettou mesmo muito bem colocada para saber a que ponto 0 era, metodologicamente. M as é um livro violento em si.

Sim, é talvez o livro mais violento que escrevi, mas num sentido muito especial da palavra.

E esse não é meu modo de ser. Eu não tinha nem a legitimidade, nem o caráter, nada, não me reconheci no modo de dizer.

Sim, sim, compreendo, mas ao mesmo tempo você estava de acordo quanto à análise. Compreendo, mas sua recusa me decepcionou muito - e a palavra é fraca.

0 senhor mesmo dizia, a assinatura de um texto é uma questão de identidade $\mathrm{N}$ ão se pode tomar a de um outro, assim, sem mais. Em realidade, durante minha colaboração com o senhor a propósito desse livro, que levou muito tempo, eu jamais havia anteci pado o quea rudeza de suas afi rmaç̧õesia resultar por escrito, eu acreditava que era vemência verbal, à qual estava muito habituada.

Q uando você diz que há al go de muito masculino, está querendo dizer um pouco machista, e concordo que há uma verdade nisso. M as ao mesmo tempo ninguém conhece melhor do que você essas condutas "heróicas" que às vezes me imponho, oralmente...

Está se referindo a algumas de suas intervenções na assembléia da École des $H$ autes Études? Estive presente lá, é verdade, inclusive um dia alguém 0 criticou publicamente por sua "falta dejeito". Era engraçado esse termo para designar um discurso que não ia no sentido normal das intervenções nesse lugar: creio que sua má vontade de falar havia colocado a assembléia pouco à vontade, e todos se sentiam "desajeitados", daí a crítica.

Sim, mas que posso me impor também por escrito, e que me valem muitas inimizades (um de meus melhores amigos deixou de me falar, por muito tempo, depois de Les H éritiers; outro ficou de mal, mas me falou, depois de "As categorias do entendimento professoral"41). É voluntarismo, e isso me custa esforços terríveis - para superar minha timidez, meu medo às vezes, porque antecipo muito bem as conseqüências -, e também muita culpa, sobretudo quando toco em instituições das quais faço parte...

41. “Les catégories de l'entendement professoral", com M . deSaint $M$ artin, Actes de la Re cherche en Sciences Sociales [1975]. 
No fundo, é parecido com o sentimento da honra...

Sim, $\operatorname{sim} .$.

M as ainda assim, quando se reflete, esse impulso da honra, que torna exigente, inflexível, no sentido de incorruptível, repousa também na idéa de que se tem sempre razão, e isso não incita à tolerância, a levar em conta circunstâncias atenuantes, por exemplo, ou subjetividades antagônicas, ou mesmo indispensáveis precauções estratégicas. É como dizer: eu e os que estão comigo temos razão.

$N$ ão éexatamenteassim, mastalvez antes detudo a idéia de quenão falo em meu nome próprio, por mim apenas. Eu sou... o porta-voz, o arauto de um coletivo oprimido, que não pode falar. Já eu, eu posso falar, então devo falar. E muitas vezes é assim: estou numa situação de privilégio que implica um dever.

Para pagar o privilégio?

Sim, um pouco. Dei-me conta de que muitas coisas em minha vida, sobretudo acadêmica, que me custavam muito, tinham por princípio esse sentimento, um pouco ridículo, do dever ligado ao privilégio... E também é aí certamente que você tem razão com sua história da honra - o medo de ser ou de parecer "covarde". 0 que me irrita um pouco é que possam crer que obedeço a uma irreprimível pulsão de gascão (que sem dúvida está presente em algumas de minhas manifestações, com freqüência um pouco fingidas...). Na maior parte do tempo, isso me custa muito.

M as há também uma gratificação em agir assim, pelo menos a auto-estima...

Sim, sim. Essa questão de machismo, de honra, de fantasma masculino do justiceiro, tudo isso não ésimples... M uitas vezes não passa de uma espé cie de fanfarronada guerreira... E ao mesmo tempo é uma das motivações para fazer al guma coisa. 0 que não quer dizer que me considero perfeito sob todos os aspectos: há coisas que eu gostaria de não ter feito, pequenos abusos de poder, inabilidades infelizes etc., mas é sobretudo as abstenções quelamento, porque geralmente o pior énão fazer nada. 
N um momento, na bibliografia, me perguntei se não era preciso pôr à parte os livros de Raisons d'A gi ${ }^{42}$. É uma questão que o senhor já havia apresentado: por que não adotar um pseudônimo para essa produção? N ão para se esconder, mas para indicar que o senhor mudava um pouco de registro. Em sociologia, busca-se adquirir uma espécie de relativi smo intelectual, todos os personagens têm suas razões; já no combate político, a gente não pode permitir-se compreender as razões do adversário. Esses pequenos livros são intervenções, eles têm um caráter muito especial. 0 senhor diz que eles não são polêmicos, mas, na medida em que servem a um combate político e foram produzidos explicitamente para isso, eles deixam de lado tudo o que a análise sociológica teria buscado, ao contrário, para fazer entrar no quadro os interesses contraditórios, as traj etórias diferenciadas, tudo o que 0 senhor chama de campo.

Não, não acho. Penso que, em La Télévision ${ }^{43}$, por exemplo, não há transgressão grave.

M as, se tivesse que descrever o campo jornalístico, o senhor não teria agido desse modo. Teríamos, sim, percebido suas preferências, mas...

Eu teria feito um trabal ho deneutralização maior, não teria nomeado $B$. H. L. [Bérnard-H enri Lévy], teria tirado um certo número de exemplos, mas no essencial teria sido a mesma coisa. Aliás, publiquei juntamente 0 prefácio do número da Actes ${ }^{44}$ e o curso: do ponto de vista do conteúdo, é praticamente a mesma coisa. U m é escrito em linguagem acadêmica, edirige-se a pessoas que levam a sério os conceitos e o método; 0 outro é dito numa forma mais soft (conceitos como o de campo são explicados numa linguagem mais simples). M as, basicamente, é um efeito do local de publicação, e assim foi visto como muito violento, de uma violência inusitada. Penso que, ao mudar delocal de publicação, o texto muda de sentido, porque muda de leitores, torna-se acessível a leitores que se excluíam até então e que trazem seus hábitos de leitura, e põem entre parênteses, de maneira consciente ou não, a construção científica (por ignorância, às vezes por incompetência) para seaterem à aned ota, às ferroadas pessoais ou às banalidades que julgam reconhecer no discurso que os ultrapassa. M as o conteúdo intelectual é o mesmo, praticamente o mesmo. Com relação a outras produções, as intervenções que apareceram em Contre feux ${ }^{45}$, é variável. Se tomarmos o texto contra Sollers, por exemplo ${ }^{46}$, éuma análise de habitus, inteiramenterigorosa (ela aponta todos os traços pertinentese somente esses),

42. "Raisons d'Agir" é uma coleção de pequenos livros, inaugurada em 1966, sob a égide de uma jovem estrutura editorial, Liber Éditions, distribuída pela Seuil. O sprimeiroslançamentos da série continham uma declaração de intenção, que evidenciavam a vontade militante dos autores.

43. Sur la télévision [1996]. 0 livro se originou do registro deum curso dado no Collège de France em 1996.

44. “'L'emprise du journalisme", Actes dela Re chercheen SciencesSodiales [1994]. 0 artigo foi re produzido como anexo no livro citado acima.

45. Contre feux [1998] eContrefeux 2. Pour un mouvement social européen [2001].

46. "Sollers tel quel", Liber. Revuelnternationale des Livres [1995], retomado em Contrefeux. 
47. "Q uestions aux vrais maîtres du monde" [1999]. que é escrita no tom de panfleto, de polêmica, mas o modelo (descritivo, explicativo e mesmo preditivo) que essa análise de habitus oferece é confirmado todos os dias. Aos que não teriam compreendido a presença desse texto num livro sobre a política de "globalização" e suas conseqüências no terreno da cultura, aconselho vivamente a leitura do último número de L'Infini, a revista de Sollers, na qual se encontrará um diálogo entre o árbitro das elegâncias do mundo literário francês e o diretor hipermidiático da Vivendi [empresa da Internet], Jean-M arie M essier, que faz a gracinha de citar René C har e de celebrar a liberdade. Em suma, acham que eu exagero quando falo de "colaboracionistas", mas não vejo outra palavra para nomear essa gente que vai "servir a sopa" aos que, como digo em minha mensagem aos donos do mundo ${ }^{47}$, estão destruindo as bases mesmas de uma vida intelectual autônoma e subjugando os "criadores".

Sim, mas, como o senhor mesmo diz, o texto tem a forma de um panfleto. 0 mal-entendido etá aí: os jovens sociólogos em formação podem imaginar que essa é a forma normal da análise sociológica, e que se pode economizar todo 0 trabalho teórico e empírico que autoriza escrever nesse tom.

Você tem razão. M as eu sei que não devo considerar como universalmente reconhecido como evidente que, para fazer um texto assim, do qual me orgulho muito e que penso ser uma de minhas obras-primas sob todos os aspectos, é preciso muita competência, muita experiência, muito savoirfaire, muita habilidade técnica (penso nas técnicas de objetivação etc.) ... E acho até que, se isso produz efeito, é porque os leitores, mesmo não profissionais, o percebem.

48. Travail et travai-

No entanto, nos seus escritos sobre a Argélia, em Travail et travailleurs ${ }^{48}$, halleursen Algérie[1963].

via claramente uma idéia política, mas era algo que podia ser lido como uma informação, a informação é que era subversiva, não o tom. Sobre a educação também.

Sim, eu sei. M as isso se deve muito à maneira de ler. D izem com fre49. La M isère du monde [1993]. qüência que mudei muito de uns anos para cá, desde La M isèredu monde ${ }^{49}$, em particular. N a verdade esquecem de se perguntar se não foi a percepção que têm de mim e de meu trabal ho que mudou muito. Por exemplo, há em Travail et travailleurs en Algérie uma conversa com um cozinheiro de Argel, intitulada "U m sociólogo espontâneo", que poderia ter sido incluída em 
La M isère du monde... embora tenham visto em La M isére uma virada epistemológica (em relação a Le M étier de sociologue [0 ofício de sociólogo ${ }^{50}$ ) e sobretudo política! $\mathrm{N}$ a verdade as pessoas que queriam isso já entendiam Travail et travailleurs ou Les Héritiers como livros políticos, neutralizando o trabalho de construção. É muito complicado! Receio que seja insolúvel. Asintervenções científicas produzem, dentro do campo e fora do campo, efeitos sociais quenão se podem controlar completamente. Portanto passei a me perguntar, a partir de um certo momento, se tinha sentido, quando se trata de assuntos importantes como o jornalismo, continuar a escrever para um pequeno mundo fechado, que não se importa com esses assuntos. E se valia a pena fazer passar as idéias mais além, o que implica que se muda um pouco o suporte e se oferecem sinais de acessibilidade.

0 que o senhor quer dizer?

Com oferecer sinais? Penso numa experiência que tive em 1981. Eu não tinha previsto em absoluto que a esquerda ganharia, não era o único... Então eu me disse: é preciso absolutamente fazer al guma coisa. Fiz uma reunião com sindicalistas, da CFDT (um deles, fiquei sabendo depois, era chamado "o professor", porque era um intelectual) e da CGT (havia um bastante conhecido e que depois saiu), e a idéia era fazer um grupo de trabalho que tentaria fornecer al gumas armas. $\mathrm{H}$ avíamos publicado um pouco antes um artigo intitulado "A produção da ideologia dominante" 51 , e 0 mostrei a esses caras, dizendo-Ihes: tomem isso, é um instrumento de combate, pode ser-Ihes útil num debate na televisão ou noutra parte. Eles me disseram: em primeiro lugar, a gente não lê esse tipo de revista; depois, se casualmente pusermos os olhos, não vemos que proveito tirar. E eu me perguntei: mas o que é uma revista científica? É uma revista que oferece sinais que são para os estudiosos e, ao mesmo tempo, que não são para os outros; que, de qualquer maneira, não diz "é também para vocês". Então, como oferecer os sinais de que "étambém para vocês" sem se expor, mesmo sem mudar nada, à desqualificação, à degradação, à excomunhão daquele que largou a batina? ("Agora ele anda escrevendo qualquer coisa”, foi o que ouvi de professores de sociologia que teriam feito qualquer coisa para publicar na Actes, e que faziam coro com a mídia, no momento da campanha deflagrada por La T éévision, para denunciar supostas faltas à cientificidade.) $\mathrm{N}$ a verdade, se "A produção da ideologia dominante" fosse retomada hoje em Raisons d'Agir, com uma página de introdução para dizer: vejam, nada
50. Le M étier de sociologue, comJ.-C. Chamboredon e J. C. Passeron [1968].

51. "La production de l'idéologiedominante", com L. Boltanski, Actes dela Rechercheen Sciences Sociales [1976]. 
mudou, é o mesmo vocabulário, "excluídos", "exclusão" etc., salvo algumas palavras novas, como "flexibilidade", que vêm dos Estados U nidos, uns 150 mil exemplares seriam vendidos.

0 senhor quer dizer: uma outra capa, um pequeno prefácio, eisso significa: "é para vocês".

Sim, mas quer dizer também queé preciso sacrificar a preocupação com a honorabilidade, a respeitabilidade acadêmica, que em muita gente se confunde com a respeitabilidade científica. Actesjá era um passo nesse sentido. A compreensibilidade deve-se em grande parte a problemas de forma, de local de publicação. M as, ao passar a linha sagrada da conveniência, evidentemente damos armas aos que levam em conta apenas o respeito à conveniência, que faz a dignidade do corpo dos profissionais. Todos esses dignos dignitários, o que eles possuem? Possuem esse pequeno espartilho de

Texto recebido em 8/ $3 / 2005$ eaprovado em 8/3/2005.

Pierre Bourdieu (19302002), um dos mais importantes sociólogos contemporâneos, autor, entre outras obras, de Os herdeiros (1964), A distinção (1979), H omo academicus (1984), As regrasda arte(1992), A miséria do mundo (1993), M editaç̃oespas calianas (1997), Esboço para uma auto-análise (2002).

YvetteD elsaut épesquisadora no CNRS e na EscoladeAltos Estudos em Ciências Sociais (exEscola Prática de Altos Estudos), no âmbito do Centro de Sociologia Européia, em Paris. E-mail:desaut@aol.com. virtude negativa. $\mathrm{N}$ ão digo que refleti sobre tudo, mas sim que, dado o que se passa no mundo neste momento, equeétão grave, não é possível, quando se é pago para se ocupar do mundo social e se é minimamente responsável, ficar em silêncio, não tentar dizer a todos um pouco daquilo que se crê ter aprendido, à custa de todos, sobre este mundo... \\ PARIS, NOVEMBRO DE 2001}

